Winter 2012

\title{
Greenpeace, Social Media, and the Possibility of Global Deliberation on the Environment
}

\author{
Michael Roose \\ Indiana University Maurer School of Law, mjroose@indiana.edu
}

Follow this and additional works at: https://www.repository.law.indiana.edu/ijgls

Part of the Environmental Law Commons, and the International Law Commons

\section{Recommended Citation}

Roose, Michael (2012) "Greenpeace, Social Media, and the Possibility of Global Deliberation on the Environment," Indiana Journal of Global Legal Studies: Vol. 19 : Iss. 1 , Article 13.

Available at: https://www.repository.law.indiana.edu/ijgls/vol19/iss1/13

This Note is brought to you for free and open access by the Law School Journals at Digital Repository @ Maurer Law. It has been accepted for inclusion in Indiana Journal of Global Legal Studies by an authorized editor of Digital Repository @ Maurer Law. For more information, please contact rvaughan@indiana.edu.

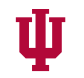

JEROME HALL LAW LIBRARY

INDIANA UNIVERSITY

Maurer School of Law
Blooming ton 


\title{
Greenpeace, Social Media, and the Possibility of Global Deliberation on the Environment
}

\author{
MICHAEL RoOSE*
}

\begin{abstract}
Greenpeace uses the developmental republican model of democratic governance for setting organizational policy. This model does an excellent job of forming members into effective leaders who are committed to the organization and its mission. However, Greenpeace could more effectively encourage the global community to become involved in environmental activism and set more responsive policy by employing an Internet-based deliberative democracy policy-setting process.
\end{abstract}

\section{INTRODUCTION}

In an age in which democracy forms the basis for the legitimacy of global governance, one would think that nongovernmental organizations (NGOs) would embrace democracy as a means of self-governance. This assumption is especially relevant in the context of NGOs that claim to act in the interest of the world's population as a whole, such as environmental organizations addressing issues that have an impact on the lives of everyone.

Greenpeace claims to value democracy as a means for global decision making ${ }^{1}$ and asserts democratic legitimacy. ${ }^{2}$ In addition, Greenpeace has made accusations that the World Trade Organization (WTO) has an undemocratic voting structure as a basis for denouncing the organization. ${ }^{3}$

* Articles Editor, Indiana Journal of Global Legal Studies; J.D. Candidate, 2012, Indiana University Maurer School of Law; B.A., 2007, Indiana University. I would like to thank Professors Susan Williams and John Applegate for their valuable feedback and guidance on earlier drafts. I would also like to thank my colleagues on this journal for editing this Note.

1. See Governance Structure, GREENPEACE INT'L, http://www.greenpeace.org/ international/en/about/how-is-greenpeace-structured/governance-structure/ (last visited Dec. 12, 2010).

2. See id.

3. See Secretive and Undemocratic, GREENPEACE INT'L, http://www.greenpeace.org/

Indiana Journal of Global Legal Studies Vol. 19 \#1 (Winter 2012)

(C) Indiana University Maurer School of Law 
However, Greenpeace itself may be subject to accusations that it lacks democratic legitimacy. Greenpeace must deal with the unresolved problems of defining the demos ${ }^{4}$ the organization represents and the ability of the demos to have an input into the activities of the organization.

Greenpeace has adopted a developmental republican structure of democratic governance, but the fundamental problem with this governance structure is that it resembles a bureaucracy rather than a democratic community of citizens. The relationship between management and participants is analogous to the hierarchical structure of a branch of the civil service. Low-level members must tolerate management's policy goals until rising to a position to change that policy, or they can leave the organization. This mechanism is effective for producing bureaucrats who carry out management's policy. Yet, in the context of environmental advocacy, the bureaucratic structure weakens the organization's ability to foster activism and to respond to grassroots environmental concerns.

The current developmental republican structure is not suited to instilling the notion of citizenship in the global populace at large, meaning that participants do not have the sense of entitlement to participate in governance or duty of loyalty that members of democratic systems should possess. Greenpeace could inspire greater amounts of environmental activism and increase the quality of its policy goals by creating a social media outlet to implement the principles laid out in deliberative democracy theory.

Section I of this Note examines the current governance structure of Greenpeace, which is based on the developmental republican model. Section II is an examination of deliberative democratic theory and a criticism of implementing developmental republicanism as a means of making policy decisions. Section III proposes a model for utilizing deliberative democracy on a global scale with social media. Section IV provides concluding remarks.

\section{A DEVELOPMENTAL REPUBLICAN MODEL OF DEMOCRACY}

Greenpeace employs a developmental republican model of democracy. ${ }^{5}$ The governance structure is representational. A select

international/campaigns/trade-and-the-environment/why-is-the-wto-a-problem/secretiveand-undemocratic/ (last visited Dec. 12, 2010).

4. This word is frequently used in literature on democratic theory and represents "the people of a nation considered as a political unit as distinguished from a tribe or kinship group." Webster's ThiRd NeW INTERnational DictionaRy 600 (1993). Demos means "populace" in Greek and shares its root with the word "democracy." Id.

5. See DAVId Held, MODELS OF DEMOCRACY 92 (3d ed. 2006), for a description of developmental republican democratic theory. 
group, drawn from Greenpeace International's (GPI) broad member base, is responsible for selecting policy goals and carrying out the dayto-day operations of the NGO. Greenpeace is republican because the organization's goal is to work toward the common good of preserving the global environmental commons. Greenpeace is developmental due to the high value it places on service to environmental organizations and causes. For the most part, voting rights are tied to a lengthy service requirement, which implies that those who have completed extended service are more virtuous and able to make better decisions in guiding the organization. The governance structures of both GPI and Greenpeace USA (GPUSA) demonstrate the organization's developmental republican character.

\section{A. Democratic, Federal Structure}

Greenpeace governs itself democratically at the international level 6 and within GPUSA.7 The organization's Web site states "Greenpeace's global governance structure reflects [the organization's] fundamental respect for global democratic principles and [Greenpeace's] need to maintain a high level of internationalism and coordination." 8 Greenpeace operates under a federal structure, facilitating international cooperation among the national and regional offices (NROs). According to the organization's Web site, GPI sits atop twentyeight NROs. ${ }^{9}$ Policy is set at the international level, and the NROs are responsible for fundraising and implementing jointly agreed global campaign strategies. ${ }^{10}$

\section{B. Greenpeace International}

GPI, "the body that coordinates global Greenpeace policy and strategy, is an organization of about 175 staff, largely based in Amsterdam." 11 GPI facilitates international cooperation, oversees the finances and management of the NROs, and attempts to expand

6. GREENPEACE INT'L, Governance Structure, supra note 1.

7. See generally AMENDED AND RESTATED BYLAWS OF GREENPEACE, INC. (2006).

8. GREENPEACE INT'L, Governance Structure, supra note 1.

9. Greenpeace Structure and Organisation, GREENPEACE INT'L, http://www.greenpeace.org/international/en/about/how-is-greenpeace-structured/ (last visited Dec. 12, 2010).

10. See id.

11. GREENPEACE INT'L, Governance Structure, supra note 1. 
Greenpeace's global presence. ${ }^{12} \mathrm{GPI}$ is composed of three main bodies: the NRO trustees, the Board of Directors, and the Executive Director. ${ }^{13}$

There are currently twenty-eight trustees, each representing their NRO at the GPI Annual General Meeting (AGM). ${ }^{14}$ Collectively, the twenty-eight trustees constitute the Council. The main responsibilities of the trustees are electing the International Board, approving the annual GPI budget ceiling, and proposing policy goals to the International Board.15 The Council has the authority to make nonbinding policy recommendations to the Board. ${ }^{16}$ The Board may choose whether to ratify that recommendation, but if it decides not to ratify, the Council may remove the Board. ${ }^{17}$

There are seven members on the Board of Directors of GPI. The International Board approves GPI's annual budget, oversees the International Executive Director and NROs, and, after discussions with the trustees at the AGM, decides Greenpeace policy on issues that the trustees identify. 18

The International Executive Director manages the administrative bureaucracy of the organization. ${ }^{19}$ The International Board appoints and supervises the International Executive Director. The International Executive Director oversees the Senior Management Team, which is composed of the directors of GPI's various administrative departments. ${ }^{20}$

\section{National and Regional Offices}

Governance and elections vary among the different national and regional offices, so I will use GPUSA's governance system as an example of a national office. The organization of GPI and GPUSA is similar in that both have an elected Board of Directors that appoint an Executive

12. Id.

13. See id.

14. See id (explaining that each NRO appoints a representative to the GPI Annual General Meeting).

15. See id.

16. Stichting GREenPeace Council, RUles of Procedure $\$ 4.1$ (2004) [hereinafter RULES OF PROCEDURE].

17. Id. §5.7.

18. See GREENPEACE INT'L, Governance Structure, supra note 1.

19. See Management Structure, GREENPEACE INT'L, http://www.greenpeace.org/ international/en/about/how-is-greenpeace-structured/management/ (last visited Dec. 12, 2010).

20. Id. 
Director. ${ }^{21}$ In both instances, the Executive Director is responsible for the day-to-day management of the organization's internal affairs. ${ }^{22}$ The two major features distinguishing GPUSA's governance system from that of GPI are the office of the Chairperson of the Board and the composition of the voting population. The Chairperson of the Board presides over meetings of the Board of Directors and represents the national office as the GPI trustee at the AGM.23

The voting membership is restricted to a narrow class of not less than forty and no more than one hundred people who contribute to and are involved in the organization. ${ }^{24}$ The features of this voting class demonstrate Greenpeace's developmental republican system of government. In order to become a voting member of GPUSA, one must apply to and receive approval from the Board of Directors. ${ }^{25}$ The Board may only enfranchise members who have completed six years of service to environmental causes, and a limited number of people for whom the Board may choose to waive the service requirement. ${ }^{26}$ The restricted voting class ensures that not only the representatives of the organization, but also the voting members themselves, are virtuous. Virtue is learned by participation in Greenpeace or one of its affiliated environmental organizations.

\section{Strengths of the Developmental Republican Model}

The developmental republican model has several strengths as a governance structure for Greenpeace: it instills virtue in its voting members through the service requirement; the voting population of Greenpeace is homogenous in its goal of protecting the environment; the most virtuous members are promoted to the positions of greatest responsibility and power; the small voting population allows for real deliberation on policy; and the democratic and deliberative processes legitimize the decisions made at the AGM to a certain extent.

As I will discuss in Section III, however, deliberative democracy through social media is a more appropriate way to set policy because that system would encourage greater deliberation. Most of the strengths

21. See AMENDED AND Restated BYLAWS OF GREENPEACE, INC., $§ 7.1$ (2006) (stipulating which of GPUSA's officers must be appointed by the Board of Directors).

22. See id. $\S 7.3$ (explaining that the Executive Director is the "general manager and chief executive officer" of GPUSA).

23. See id. $\S 7.2$. Members of the Stichting Greenpeace Council, for the most part, are trustees sent from the national offices to attend the Annual General Meeting. RULES OF PROCEDURE, supra note $16, \S \S 4.4-4.5$.

24. Id. $\$ 2.1$.

25. See id. (explaining the requirements one must meet to become a voting member).

26. Id. 
above are best suited to developing a loyal group of bureaucrats who can protect the organization from financial problems, prevent hijacking by parties adverse to Greenpeace's mission, and carry out its policy goals.

Developmental republicanism and an effective bureaucracy require citizens who are virtuous and homogenous. The service requirement is an effective filter for allowing only those who are virtuous and committed to the organization to vote on policy. Requiring six years of service prevents both Greenpeace's enemies and those who do not embrace the organization's aims from actively participating in the organization. Voting members have already demonstrated their allegiance to the organization by contributing a substantial portion of their lives to its activities. The service requirement has the added benefit of producing voting members who share a conception of what is best for the environment. Also, the service requirement gives voting members an understanding of the inner workings of the organization. The developmental republican model grooms members to become more effective institutional leaders in the future, ensuring the continued existence of Greenpeace as an organization.

Greenpeace's upward filtration process is similar to what James Madison describes in Federalist Number $10,{ }^{27}$ producing a small body of the most virtuous citizens who then set organizational policy. The voting members choose the national and regional Board of Directors, ${ }^{28}$ whose members then choose the trustees. ${ }^{29}$ These members then vote, along with the other trustees from the NROs, for International Board of Directors members and on organizational policy. ${ }^{30}$ The filtration process promotes knowledgeable and skillful bureaucrats who are committed to protecting the organization from insolvency and who are able to implement policy goals. Additionally, each level of voting acts as another filter to allow only the most virtuous Greenpeace members to set GPI's global policy, preventing parties adverse to Greenpeace from participating in governance.

The approximately thirty-five participants in the AGM can make virtuous policy decisions because the small number of members allows trustees and Board members to meet in-person. Through a process of deliberation, given the limits of their knowledge and experience, they

27. See James Madison, The Federalist No. 10, in THE FEDERAlist with LetTers of "BRUTUS" 44 (Terence Ball ed., 2003) ("The effect of [representative government] is . . . to refine and enlarge public views, by passing them through the medium of a chosen body of citizens, whose wisdom may best discern the true interest of their country, and whose patriotism and love of justice, will be least likely to sacrifice it to temporary or partial considerations.").

28. AMENDED AND RESTATED BYLAWS OF GREENPEACE, INC., supra note 7, § 5.1.

29. Id. $\S$ 7.1-7.2.

30. GREENPEACE INT'L, Governance Structure, supra note 1. 
can discover the global common good in the field of environmentalism. Such a small decision-making body allows the Council to do more than simply conduct yes-or-no votes on agenda items. Instead, the size of the Council allows the members to engage in meaningful discussion on policy. The actions of the Council are legitimized by both the democratic process that elected the trustees and Board members and by the fact that the decisions were reached in a deliberative, rather than selfinterested, manner.

Thus, there are three major strengths of the Greenpeace developmental republican governance system: fostering virtue and homogeneity in its members before they are enfranchised, allowing the democratic process to promote the most virtuous members, and legitimizing the decisions of the Council by creating a forum conducive to deliberation. As a result, members at the highest level of Greenpeace are able leaders who can succeed in implementing policy and ensure the continued existence of the organization. Yet, as the next section demonstrates, while the Council's size is conducive to deliberation, a social media platform where everyone may participate would be a better way to determine appropriate policy areas to focus resources.

\section{InCREASing PaRticipation In Policy Decisions Through DELIBERATIVE DEMOCRACY}

Developmental republicanism is a strong means for preserving the long-term solvency of the organization and for efficiently implementing policy. Consequently, as an executive body, the International Board works well. Yet, analyzing the current Greenpeace decision-making process from the perspective of deliberative democracy, as articulated by Iris Marion Young and Seyla Benhabib, yields two major criticisms. First, very few members of Greenpeace, let alone those influenced by Greenpeace policy, actually play a role in setting the organization's policy. Second, by allowing the global community more control over, and input into, the decision-making process, Greenpeace could take advantage of opportunities to increase participation in environmental activism and the responsiveness of its policy by reaching beyond the limited knowledge and perspective of its own homogenous membership.

The current restrictions on participation in policy deliberation represent a form of paternalism that discourages potential activists from becoming involved in Greenpeace. Very few people control the issues to which Greenpeace devotes its resources, but the organization's activities have an impact on the global commons. Only registered members consent to the organization's influence, and those who disagree with Greenpeace's policies have no means of eliciting change. 
Viewed in this light, Greenpeace resembles a faction more than a democratic institution.

In addition to hindering participation in Greenpeace, the developmental republican policy-setting structure reduces the quality of policy. Under the current model, new environmental causes filter up through the organization, potentially leading to bureaucratic groupthink. As members rise through the organization, their local contacts must necessarily decrease due to time constraints, and those members might become ideologically homogeneous on many matters. Greenpeace could increase the quality of its decision making by providing a platform for people to raise awareness of issues impacting their lives, allowing resources to be allocated to the causes that need the most attention.

\section{A. Who Does Greenpeace Represent?}

As John McGinnis, a scholar of international law, illustrates, there is confusion as to who Greenpeace's constituency includes. He states, "Greenpeace is a predominantly Western organization whose views are unrepresentative even of many citizens in the West. NGOs are essentially transnational factions . . .."31 Within this statement, there are two competing visions of whom Greenpeace represents. The organization may act on behalf of either its members, forming an international faction, or on behalf of all citizens of the global community.

Ultimately, Greenpeace's constituency is the entire world, but the current paternalistic policy-setting mechanism discourages its demos from devoting time or resources to the organization. Greenpeace itself claims to "speak for 2.8 million supporters worldwide." 32 Thus, strictly speaking, the demos that Greenpeace purports to represent are composed only of registered Greenpeace members. The source of Greenpeace's democratic legitimacy, then, rests on the fact that members are free to register and disassociate at any time, expressing their explicit consent to be associated with the organization's policies. Greenpeace, however, "encourages many millions more than [their members] to take action every day," 33 implying that the population for whom the organization speaks is broader than its member base.

31. John O. McGinnis, The Appropriate Hierarchy of Global Multilateralism and Customary International Law: The Example of the WTO, 44 VA. J. INT'L L. 229, 245 (2003).

32. About Greenpeace, GREENPEACE INT'L, http://www.greenpeace.org/international/ en/about/ (last visited Dec. 12, 2010).

33. Id. 
Regardless of its official stance, Greenpeace is effectively speaking for the global citizenry because the organization's policies affect the environment, which belongs to everyone. While arguing in favor of deliberative democracy, Benhabib writes that "only those norms . . . can be said to be valid ... which would be agreed to by all those affected by their consequences." 34 Therefore, everyone who is impacted by Greenpeace's procedural and substantive decisions would have to agree in order for them to be legitimate. She goes on to add that "environmental issues in general are a perfect example of such instances when the boundaries of discourses keep expanding because the consequences of our actions expand and affect increasingly more people." 35 Use of the global commons in an irresponsible manner affects the entire world, so policies regarding how environmental organizations employ their resources are relevant to everyone.

Greenpeace's limited voting class discourages people from participating in the organization. As the previous analysis of the GPUSA voting structure demonstrates, the organization-wide enfranchised population is quite small. It is currently restricted to two types of people: those who complete the six-year service requirement and those ten people or fewer that the Domestic Board enfranchises for other reasons. Unsurprisingly, as with any organization of this scale, Greenpeace has critics, both internal and external. There are no means available for dissenters to participate in the organization's decisions, even when Greenpeace's policy affects the lives of everyone. Indeed, in order to participate in the governance of Greenpeace, people are effectively required to complete six years of service, working to implement policies with which they disagree. Whereas the loyalty of bureaucrats to top-down policies is valuable in an executive body, excluding all other global citizens leads to a lack of motivation to participate.

Greenpeace fails to provide a valid basis for its paternalistic influence on the lives of nonmembers. To legitimately act on behalf of the global community as a whole and to justify its claims to democratic legitimacy, the organization should increase participation in decision making beyond the homogenous cabal of voting members. Beyond the few thousand worldwide voting members, access to the organization as a means to give input is nearly nonexistent. The fact that so few people are enfranchised inhibits the organization's ability to inspire grassroots

34. Seyla Benhabib, Toward a Deliberative Model of Democratic Legitimacy, in

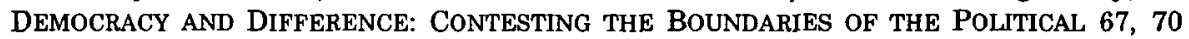
(Seyla Benhabib ed., 1996).

35. Id. 
participation, and the current model provides no answer to Benhabib's definition of the demos as all who are affected.

\section{B. Filtration of Ideas and Experience}

Greenpeace's agenda-setting procedure creates a large gap between the global community and the International Board elites by failing to incorporate the diversity of perspective that is present in the world. The current governance structure provides a mechanism to filter ideas for new policy decisions up the internal hierarchy, eventually moving from a registered member to the Council and International Board. ${ }^{36}$ Presumably, the Council does an adequate job of deliberating, but only if one takes into consideration the limited knowledge and narrow range of issues with which the Council deals. By expanding participation to include the whole of humanity, Greenpeace could improve the quality of deliberation, as worldwide deliberation would place power in the hands of a truly diverse decision-making body, rather than the homogenous Council.

Young writes that "[p]reserving and listening across ... differences of position and perspective causes the transformation in preference that deliberative theorists recommend." 37 She proposes three causes of this transformation that provide a basis for criticizing the current filtration system for selecting policy areas upon which to focus resources: selfreflection, the transformation of self-interest into appeals to justice, and the development of shared knowledge. ${ }^{38}$

First, Young states that "[c]onfrontation with different perspectives, interests, and cultural meanings teaches me the partiality of my own, reveals to me my own experience as perspectival." 39 As noted above, the Council is largely homogenous in that its members are environmentalists who have spent a great deal of time in the organization. All of the members have been filtered through the demanding selection process. While allegiance to Greenpeace is beneficial when selecting people to look after the long-term health of the organization, the selection process effectively eliminates dissent from the status quo. Expanding the deliberation to include the entire world would oblige the decision makers to confront people who are different from them, thereby forcing them to recognize the concerns of others and reconsider their own perspectives.

36. See GREENPEACE INT'L, Governance Structure, supra note 1.

37. IRIS MARION Young, INTERSECTING VoICES: DILEMMAS OF GENDER, POLITICAL PHILOSOPHY, AND POLICY 68 (1997).

38. See id. at 68-69.

39. Id. at 68 . 
Second, Young states that this recognition of diversity "forces me to transform my expressions of self-interest and desire into appeals to justice." 40 While the Council likely thinks that it is formulating just, fair policy, without exposure to people "with different perspectives, interests, and cultural meanings," the deliberation does not cause the transformation in preferences that is the goal of deliberation. Young claims, "plural public perspectives require such expressed claims to appeal across difference, to presume a lack of understanding to be bridged, thus transforming the experience itself." 41 Under a global deliberative model, policy decisions justified in terms that appeal only to environmentalists would not suffice, whereas the Council does not have to provide reasons for its decisions to anyone except other high-level members. The process of policy development must be more inclusive of the views of those outside the cadre of dedicated environmentalists.

Finally, Young asserts that deliberation imparts information, 42 and Greenpeace's filter process does not provide an adequate method to inform Council members in their low-participation deliberation. In a related discussion, Benhabib writes "no single individual can anticipate and foresee all the variety of perspectives through which matters of ethics and politics would be perceived by different individuals; and ... . no single individual can possess all the information deemed relevant to a certain decision affecting all." 43 These two criticisms are particularly relevant to Greenpeace, because the twenty-eight-member board can hardly be said to possess the collective knowledge of the twenty-eight NROs they represent, ${ }^{44} 2.8$ million members, ${ }^{45}$ and the global community. Young asserts that "through listening across difference each position can come to understand something about the ways proposals and claims affect others differently situated." 46 Not only is knowledge of subject areas increased, but also expanded participation contributes to deeper knowledge of global interconnectedness and effects on others.

\section{INTERNET-BASED DELIBERATION}

Raising the level of participation in the process of deliberation beyond the current voting membership would encourage greater

40. Id.

41. Id. at 68-69.

42. Id. at 69 .

43. Benhabib, supra note 34 , at 71 .

44. GREENPEACE INT'L, Governance Structure, supra note 1.

45. GREENPEACE INT'L, About Greenpeace, supra note 32.

46. YounG, supra note 37, at 69. 
participation in environmental activism and improve the quality of decisions without sacrificing the most important strength of the developmental republican model. That is, to preserve Greenpeace as an institution by placing experienced members committed to the organization in positions of responsibility for controlling finances and successfully implementing projects. A major perceived drawback of the deliberative system is the lack of scalability, ${ }^{47}$ but establishing the Internet-based forum for deliberation that I propose would allow participation of all who have access to the Internet, providing global citizens with an entry into environmentalism and improving the quality of the deliberation by integrating a diversity of perspectives into the dialogue.

\section{A. Defining Deliberation}

Merely expanding participation would not necessarily improve policy making. To test the deliberative character of my model forum for discourse, I will analyze it through the democracy theory of Benhabib, while also incorporating the criticism of Young into my own characterization of legitimate discourse.

Benhabib provides three rules for discourse that serve to legitimize the resulting decision-making process and substantive policy, all of which are underpinned by the values of inclusion, freedom, and equality. ${ }^{48}$ The first rule of discourse that Benhabib articulates is that "participation in such deliberation is governed by the norms of equality and symmetry, all have the same chances to initiate speech acts, to question, to interrogate, and to open debate." 49 The second rule of discourse is that "all have the right to question the assigned topics of conversation." 50 The final rule of discourse that Benhabib lists is that "all have the right to initiate reflexive arguments about the very rules of the discourse procedure and the way in which they are applied or carried out." 51 The three rules are the equal opportunity to initiate speech, set the agenda, and establish procedure.

In addition to Benhabib's rules of discourse, Young points out that the style of acceptable discourse must not be limited to critical

47. By "lack of scalability," I mean that while deliberative democracy works well on a small scale, it is often said to be impractical when the number of participants becomes too great.

48. See Benhabib, supra note 34 , at 69 (discussing inclusion in terms of collective deliberation).

49. Id. at 70 .

50. Id.

51. Id. 
argument because doing so excludes a large number of people. ${ }^{52}$ She states "bracketing political and economic power is [not] sufficient to make speakers equal" and claims that people do not have the same sense of entitlement to the right to speak or speak in a manner that carries as much weight in the context of a critical argument. ${ }^{53}$ She states that

[i]n many formal situations the better-educated white middle-class people . . : often act as though they have a right to speak and that their words carry authority, whereas those of other groups often ... do not speak, or speak only in a way that those in charge find "disruptive." 54

The forum, then, must not be structured as a critical argument, or large segments of the population will not participate. Also, the rules of the discourse must allow for speech that is neither "formal and general" 55 nor "dispassionate and disembodied," 56 because while those forms of speech are considered valuable among elites in the West, those limits on the discourse are culturally biased and serve to exclude people who are not from privileged backgrounds. 57 These considerations are particularly important when trying to foster global participation because eliminating de jure exclusion is worthless if de facto exclusion is still operating.

\section{B. The Model}

As a basis for the model of Internet-based deliberative democracy I propose, I draw from Beth Simone Noveck's deliberative electronic democracy tool, Unchat. ${ }^{58} \mathrm{My}$ model differs from Unchat in several respects, mainly in that my model is more decentralized to accommodate a much greater participation and is less wary of irrational modes of communication. The Web site Digg.com is an example of a forum that could be adapted to facilitate the implementation of a deliberative democracy model in the context of Greenpeace.

\footnotetext{
52. See YounG, supra note 37 , at 60 .

53. Id. at 63 .

54. Id. at 64 .

55. $1 d$.

56. Id.

57. See id. at 64-65 (arguing that the "speech cultures" of women and racial minorities are devalued compared to the "speech culture" of white, middle-class men).

58. See generally Beth Simone Noveck, Designing Deliberative Democracy in Cyberspace: The Role of the Cyber-Lawyer, 9 B.U. J. SCI. \& TECH. L. 1 (2003).
} 
Digg.com is a social media Web site that, in October 2011, is estimated to have received over 4.3 million visitors. ${ }^{59}$ According to Digg.com,

Digg is a place for people to discover and share content found on the web. From the biggest online destination to the most obscure blog, Digg surfaces the best stuff as voted on by our users. You won't find editors at Diggwe're here to provide a place where people collectively determine the value of content." 60

Links that receive the most votes are listed on the front page and user traffic to those links "regularly overwhelm[s] and temporarily shut[s] down websites in a process called the 'Digg Effect."'61

Greenpeace could establish a similar forum in which people would meet to deliberate on what policy objectives the organization should adopt, through a process of posting links to articles, videos, and images. Such a model would serve to alleviate two related problems in implementing organization-wide deliberative democracy: conducting real deliberation that includes such a large number of people and producing decisions that are representative of the global community.

\section{Fostering Real, Organization-Wide Deliberation}

Noveck writes that "[c]yberspace is flexible enough that users ought to be able to convene in different sorts of spaces according to the rules they set for themselves." 62 The goal of this model is to produce deliberation that meets Benhabib and Young's characterization of discourse by providing adequate opportunity for universal participation.

My model would allow the global community to control what items will be on the agenda, fulfilling the first of Benhabib's requirements for deliberation. Participants would be able to post links that they considered important to setting the organization's annual policies. There would be no restrictions on content, but members would be free to vote for links to bring them onto a prominent list of the most popular webpages. Only content that a large number of users find relevant and

59. Digg.com Traffic and Demographic Statistics by Quantcast, QUANTCAST, http://www.quantcast.com/digg.com (last visited Dec. 22, 2011).

60. Frequently Asked Questions: Digg About, DIGG, http://about.digg.com/faq (last visited Dec. 22, 2011).

61. Oleoleolson, Massive Censorship of Digg Uncovered, ALTERNET (Aug. 5, 2010, 4:40 AM), http://blogs.alternet.org/oleoleolson/2010/08/05/massive-censorship-of-digg-uncovered/.

62. Noveck, supra note 58, at 69. 
favorable would reach that list. Otherwise, the links would lie dormant, stuck at the preliminary stage. The members themselves would have complete democratic control over agenda items in this way.

In addition to the ability to post stories, Benhabib's requirement that participants "all have the same chances to initiate speech acts, to question, to interrogate, and to open debate" 63 would be met by a comment feature. Users would have the opportunity to right incorrect assertions contained in the webpage, and other members would have a chance to rebut those claims of falsehood by providing other links or making original appeals. Comments themselves would also be subject to democratic vote, and comments receiving the most votes would rise to the top of the stack. The user's comments would remain available at the bottom of the page so as not to act as a censor to speech.

To fulfill Benhabib's final requirement, users would also be able to propose reforms to the process by which the forum operates. Stories on Digg.com often propose changes to the structure by which the Web site is governed.64 In fact, these rules have been changed. In May 2009, a right-wing cartel, called the Digg Patriots, organized itself to effectively control the agenda, ${ }^{65}$ and Digg.com temporarily suspended the "bury" feature in reaction to that episode. ${ }^{66}$ For this reason, any online Greenpeace forum for deliberation must provide the opportunity to police the forum and enforce the rules of discourse.

Much of the problem Digg.com faces is that users are anonymous and banning them is nearly impossible. As Noveck writes:

[W] hen communication functions as a means for public decision making and not as entertainment, participants must be identifiable and accountable. Being known by name encourages responsible participation because it connects public action with personal reputation. In a chat room where participants are not accountable, there are no consequences, even for opinions that are destructive and prejudicial. 67

63. Benhabib, supra note 34 , at 70 .

64. See, e.g., Digg This if You Are Sick of Power Users Stealing Stories, DigG, http://digg.com/news/story/Digg_this_if_your_sick_of_power_users_stealing_stories (last visited Dec. 12, 2010).

65. See Oleoleolson, supra note 61.

66. See id.

67. Noveck, supra note 58, at 70 (partially citing AMY GUTMANN AND DENNIS ThOMPSON, DEMOCRACY AND DISAGREEMENT 128-64 (1996) and parenthetically noting that "Chapter 4 discusses the role of accountability in deliberative processes"). 
As a result, Greenpeace should require that voting users identify themselves by name. One can imagine a situation in which a target of Greenpeace action could hijack the forum and effectively silence the organization's criticism. The identification requirement would at least constrain such organized efforts because participants would be restricted to one vote per name. In addition, tying access to a person's real world identity would give the Greenpeace community the opportunity to impose temporary bans on people who repeatedly violate the rules of discourse.

Finally, Young's concerns would be relieved by the fact that debate would not be constrained to "formal and general" 68 or "dispassionate and disembodied"69 textual argument. This is because the Internet provides an opportunity to use photographs, audio, and video as a means of transforming the preferences of others. Given the problem of translation, the visual media would likely play an enhanced role in the selection of policy. Seeing pictures of an environmental disaster, for example, may more easily sway a voter to one's cause than verbal persuasion. Also, elites constitute a fraction of the possible participants and would not control the discourse as a judge in a courtroom does, so proponents of a specific issue would not benefit from appealing in a manner persuasive to anyone except the participants themselves.

\section{Access to Technology and Exclusion}

While this model of governance would increase awareness of and participation in environmental issues and improve Greenpeace's responsiveness to grassroots concerns, the Internet-based forum would exclude many people from the decision-making process. For now, this model does not alleviate the problem that "Greenpeace is a predominantly Western organization whose views are unrepresentative even of many citizens in the West" 70 and may even exacerbate the legitimacy problem. Yet, despite problems of access to the Internet and disparities in skill and time, the benefits of an Internet-driven deliberative democracy render it an improvement over the current governance structure.

The Internet is not accessible to all people, so some voices would necessarily be excluded from a deliberative democratic Greenpeace. According to one source, only 30.2 percent of the world's population has access to the Internet, whereas 58.3 percent of Europeans and 78.3

68. YoUNG, supra note 37 , at 64 .

69. Id.

70. McGinnis, supra note 31 . 
percent of North Americans have access. ${ }^{71}$ Greenpeace is already characterized as a predominantly Western organization, and adopting an Internet-based deliberative democracy would give more volume to the already-loud Western voices. Yet, this gap in Internet access is shrinking. In Latin America, the Middle East, and Africa, the number of Internet users has grown 1,037.4 percent, 1,987.0 percent, and 2,527.4 percent, respectively, over the last ten years. ${ }^{72}$ During the same period, growth in North America and Europe was only 151.7 percent and 353.1 percent respectively. ${ }^{73}$ While a disparity in the ability to participate in the governance of Greenpeace would exist temporarily, the issue seems to be resolving itself. The advantages of an increase in participation outweigh the short-term disadvantages.

Another cause for concern is the Internet-based model would also allow those with the most technological skill and free time to have a disproportionately larger influence on matters. Young people are more likely to possess the skills needed to use technology in its greatest capacity, giving them a larger voice. As the Internet becomes more widespread, though, this difference will level out. The more pressing concern is that those with the most free time would theoretically be able to cast more votes than those who spend the majority of their time working, going to school, or caring for children. Time is a resource, and to render users more equal, a daily cap could be placed on all users' number of votes. Of course, this limit would disadvantage users who care the most about the governance of Greenpeace, but deliberative democracy does not merely require that people be free, but also equal. ${ }^{74}$

\section{CONCLUSION}

Greenpeace's current developmental republican governance structure lends itself well to maintaining the financial solvency of the organization and to executing its policy goals quickly and successfully. Yet, the organization's activity lacks democratic legitimacy due to the inability of those whom its projects affect to participate in policy making. Furthermore, no effective channel for providing criticism exists. The service requirement for voting is an obstacle that discourages people from participating in the organization. At the same time, Greenpeace could improve the quality of its decisions by empowering people from diverse backgrounds with different needs to meet,

71. World Stats, INTERNET WORLD STATS, http://www.internetworldstats.com/stats.htm (last visited Dec. 22, 2011).

72. Id.

73. Id.

74. Benhabib, supra note 34 , at 69. 
communicate, and set the policy goals of the organization. The Internet might allow for global dialogue that comports to the model described in deliberative democratic theory, solving the scalability problem that has prevented deliberative democracy from moving beyond small settings. 